\title{
42. GEOCHEMISTRY OF ROCKS ABOVE TRACHYTE BASEMENT AT DEEP SEA DRILLING PROJECT SITE 465, SOUTHERN HESS RISE ${ }^{1}$
}

\author{
Walter E. Dean, U.S. Geological Survey, Denver, Colorado \\ and \\ Martha R. Scott and George W. Bolger, Texas A\&M University, College Station, Texas
}

\begin{abstract}
Samples of laminated limestone above trachyte basement in Deep Sea Drilling Project Hole 465A were analyzed for 27 major, minor, and trace elements, to test for contributions of metals from hydrothermal sources. These samples are slighty enriched in several elements, especially $\mathrm{Mo}, \mathrm{Ni}, \mathrm{V}$, and $\mathrm{Zn}$. However, the relatively high concentration of $\mathrm{Al}$ in these samples and the lack of significant enrichment in $\mathrm{Fe}, \mathrm{Mn}, \mathrm{B}$, and $\mathrm{Ba}$ indicate that introduction of metals by hydrothermal solutions venting at the sea floor is unlikely.
\end{abstract}

\section{INTRODUCTION}

Sediments containing high concentrations of certain elements (particularly $\mathrm{Fe}, \mathrm{Mn}, \mathrm{Ba}, \mathrm{B}, \mathrm{As}, \mathrm{Cd}, \mathrm{V}, \mathrm{Cu}$, $\mathrm{Ni}, \mathrm{Co}, \mathrm{Cr}$, and $\mathrm{Zn}$ ) have been reported in association with active crustal-spreading centers such as the East Pacific Rise and adjacent Bauer Deep (e.g., Boström and Peterson, 1969; Boström et al., 1969; Boström, 1970; Dymond et al., 1973; Sayles and Bischoff, 1973; Sayles et al., 1975; Heath and Dymond, 1977; Spiess et al., 1980) and the Mid-Atlantic Ridge (Rona, 1976; Rona et al., 1976; Varentsov, 1978). The most spectacular examples of metal concentrations associated with an active spreading center are the massive polymetallic sulfide deposits on the East Pacific Rise at about $21^{\circ}$ north latitude (Corliss et al., 1978; Natland et al., 1979; Hekinian et al., 1980). Studies of these sediments have shown that significant amounts of metals are contributed by hydrothermal solutions. Hydrothermal metal enrichment in sediments not associated with active spreading centers has also been reported from the western Philippine Basin (Bonatti et al., 1979) and Parece Vela Basin (Scott and Bolger, in press) of the Philippine Sea, and in the northeast-Pacific manganese-nodule area between the Clipperton and Clarion fracture zones (Bischoff and Rosenbauer, 1977).

Hess Rise, a large, mid-ocean plateau, possibly formed at a spreading center. If so, the basal rocks of the plateau should show evidence of the type of metal enrichment commonly found near active mid-ocean spreading centers.

\section{METHODS}

Eleven samples of laminated limestone (Lithologic Unit II; see Site 465 report, this volume) were collected over a distance of 2 meters immediately above trachyte basement in Core 40 , Hole $465 \mathrm{~A}$, to test for contributions of metals from hydrothermal sources. A summary of lithologies in Core 40 and locations of samples are shown in Figure 1.

Samples were air-dried and ground in a ceramic mill to pass a 100 -mesh $(149-\mu \mathrm{m})$ sieve. One split of each of the 11 samples was

\footnotetext{
1 Initial Reports of the Deep Sea Drilling Project, Volume 62.
}

analyzed in the analytical laboratories of the U.S. Geological Survey for 27 major, minor, and trace elements, by a combination of optical emission spectroscopy, X-ray fluorescence, and atomic-absorption spectrophotometry. Details of the analytical methods are described in the analytical sections of a report by Miesch (1976).

A second split of each sample was analyzed for $\mathrm{Al}, \mathrm{Fe}, \mathrm{Mg}, \mathrm{Mn}$, $\mathrm{Cu}, \mathrm{Co}$, and $\mathrm{Ni}$ by atomic-absorption spectrophotometry at Texas A\&M University. Aliquots of 0.3 to 0.5 grams were weighed to the nearest $10 \mu \mathrm{g}$ in teflon beakers and dissolved in concentrated reagentgrade $\mathrm{HCl}, \mathrm{HNO}_{3}$, and $\mathrm{HF}$. The samples were then dried, redissolved in concentrated $\mathrm{HCl}$, and diluted to $100 \mathrm{ml}$ final volume with distilled water ( $1 \% \mathrm{HC} 1$ matrix). Additional samples of USGS standards JB-1 (basalt) and MAG-1 (marine mud) were digested concurrently for accuracy determinations. The analyses were performed with an air-acetylene flame for $\mathrm{Mg}, \mathrm{Fe}, \mathrm{Mn}$, and $\mathrm{Cu}$, a nitrous-oxide-acetylene flame for $\mathrm{Al}$, and flameless atomic absorption for $\mathrm{Co}$ and $\mathrm{Ni}$. Concentrations were determined by comparison with appropriate dilutions of standards, with a precision of better than $\pm 5 \%$ for all elements. Comparison of experimental results with published values for JB-1 (Flanagan, 1973) and MAG-1 (Manheim et al., 1976) showed that recoveries were within $\pm 6 \%$ of the published values for $\mathrm{Mg}, \mathrm{Fe}$, and $\mathrm{Cu}$, and within $\pm 10 \%$ of the published values for $\mathrm{Co}$ and $\mathrm{Ni}$.

\section{RESULTS}

Results of analyses for 27 elements in 11 samples from Core 40, Hole 465A, are plotted versus sub-bottom depth in Figure 2. Mean concentrations of elements in laminated limestone of Lithologic Unit II are indicated by arrows on the plots in Figure 2 and are listed in Table 1. Plots of element concentrations above Core 40 and a list of element concentrations for samples from Core 40 and above are given in a report by Dean (this volume).

The top six samples from Core 40 , to a depth of 410.63 meters sub-bottom, are laminated, olive-gray limestone typical of Lithologic Unit II (Fig. 1; see Site 465 report, this volume). A zone of obvious mineralization begins with the seventh sample $(410.89 \mathrm{~m}$ subbottom), which is laminated limestone like the top six samples, but with large, euhedral calcite crystals. The eighth sample (411.01 m sub-bottom) is laminated volcanic ash. The ninth sample (411.32 m sub-bottom) is dolomite with barite and pyrite. The tenth and eleventh samples (411.56 and $411.65 \mathrm{~m}$ sub-bottom) are volcanic ash. 


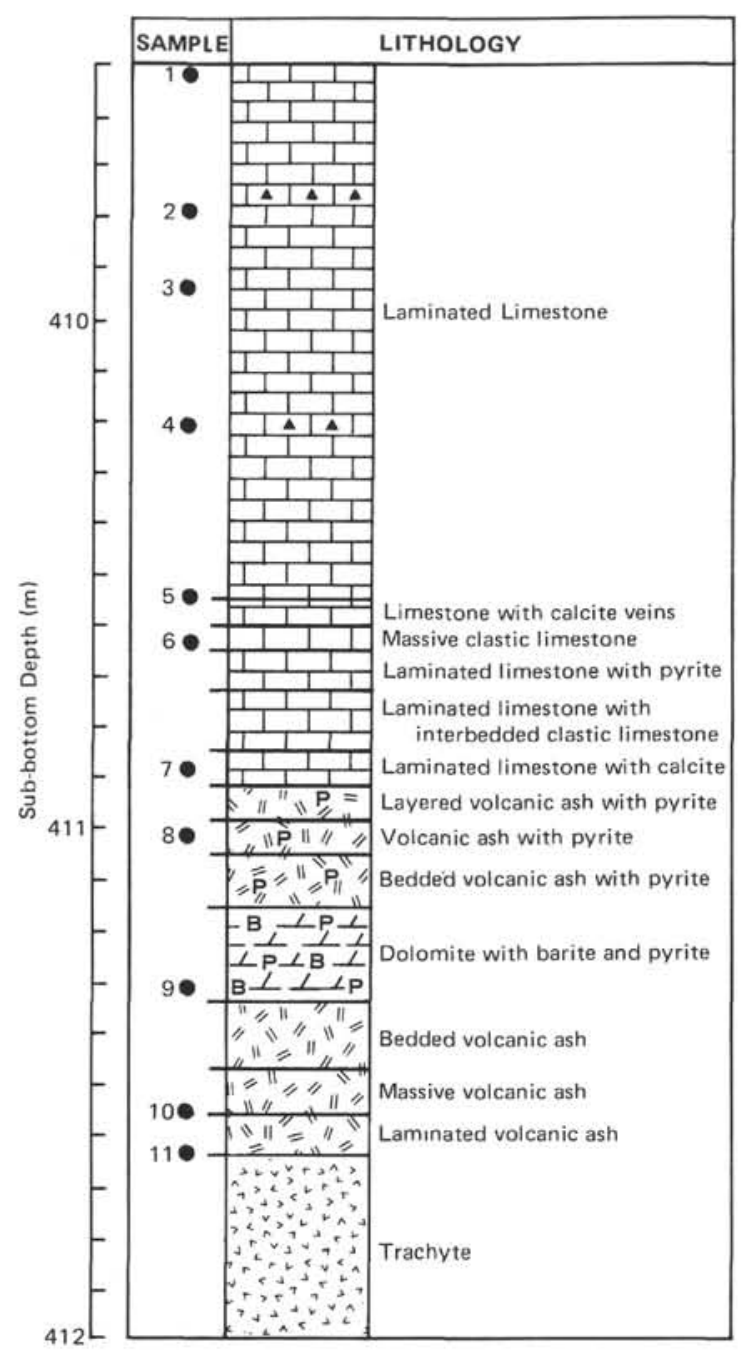

Figure 1. Lithologic summary of Core 40 , Hole 465 A, from 409.5 to 412 meters sub-bottom, showing locations of samples discussed in this report.

Most of the elements charted in Figure 2 show one of two patterns of concentration versus depth. The first pattern, illustrated by $\mathrm{Cr}, \mathrm{Cu}, \mathrm{Mo}, \mathrm{Ni}, \mathrm{Sc}, \mathrm{Sr}, \mathrm{V}$, and $\mathrm{Zn}$, is a decrease in concentration in laminated limestone down to the mineralized zone $(\sim 410.6 \mathrm{~m}$ subbottom), with low concentrations in the three samples of volcanic ash (samples 8, 10, and 11). However, concentrations of these elements at the top of Core 40 are higher than average for the laminated limestone of Lithologic Unit II (indicated by arrows in Fig. 2), and decrease to values that are about average for Unit II. This pattern shows particularly well in plots or $\mathrm{Ni}, \mathrm{V}$, and $\mathrm{Zn}$ in Figure 2.

The second pattern, illustrated by $\mathrm{Si}, \mathrm{Al}, \mathrm{Na}, \mathrm{K}, \mathrm{Ti}$, $\mathrm{B}, \mathrm{Be}, \mathrm{Ga}, \mathrm{La}, \mathrm{Li}$, and $\mathrm{Zr}$, is the result of higher concentrations of these elements in volcanic ash than in laminated limestone. Concentrations of these elements in the laminated limestone above the mineralized zone (top six samples) are more or less constant and about average for the laminated limestone; they then increase in the mineralized laminated limestone (sample 7) and volcanic ashes (samples 8,10 and 11). The plots for $\mathrm{Si}$, $\mathrm{Al}, \mathrm{B}$, and $\mathrm{Li}$ show this pattern particularly well.

The concentration of $\mathrm{Mg}$ shows a pattern similar to the second pattern, except that the lowest two laminated-limestone samples (samples 5 and 6) are enriched in $\mathrm{Mg}$, with concentrations similar to those in the volcanic-ash layers. The concentration of Mn shows a pattern similar to that for $\mathrm{Mg}$, except that the ash samples are not enriched, and enrichment of $\mathrm{Mn}$ in the laminated limestone occurs to a higher stratigraphic level (above $410 \mathrm{~m}$ sub-bottom).

Concentrations of $\mathrm{Fe}$ are only high in those samples that contain pyrite. The concentration of $\mathrm{Ba}$ is very high in the barite-bearing dolomite bed $(411.32 \mathrm{~m}$ subbottom), and slightly elevated in the lower two ash layers. Concentrations of $\mathrm{Pb}$ are only slightly elevated in the lower two ash layers.

\section{DISCUSSION}

The element-concentration patterns shown in Figure 2 and discussed above indicate that laminated limestone is enriched in some elements relative to average laminated limestone of Lithologic Unit II, for as much as 2 meters above trachyte basement. This enrichment is particularly evident for $\mathrm{Mo}, \mathrm{Ni}, \mathrm{V}$, and $\mathrm{Zn}$, and to a lesser extent for $\mathrm{Mg}$ and $\mathrm{Mn}$.

The laminated limestone is enriched in organic matter throughout Lithologic Unit II and contains up to $9 \%$ organic carbon (see Dean et al., this volume). Some trace-element enrichment may be due to concentration of these elements in organic matter, but if so we would expect high concentrations throughout Unit II, not the marked decrease above 410 meters sub-bottom. In fact, some elements concentrated in the bottom 1.5 meters of Unit II-especially Mo, Mn, Ni, and V-are suspected of being enriched by bioconcentration in most of the organic-carbon-rich limestone of Unit II (see Dean, this volume).

Sediments affected by hydrothermal solutions tend to be particularly enriched in $\mathrm{Fe}$ and $\mathrm{Mn}$ and depleted in $\mathrm{Al}$ and Ti (Boström and Peterson, 1969; Boström, 1970; Bischoff and Rosenbauer, 1977). Data on relative enrichment or depletion of various elements are usually based on carbonate-free concentrations. Our samples were not analyzed for $\mathrm{CaCO}_{3}$, so we were unable to compute concentrations of elements on a carbonate-free basis, but this problem can be eliminated by using ratios or by expressing relative concentrations on a triangular diagram. The base of the laminated-limestone unit does not show the enrichment in $\mathrm{Fe}, \mathrm{Mn}, \mathrm{B}$, or $\mathrm{Ba}$ that is characteristic of hydrothermal sediments and rocks (Boström et al., 1969; Heath and Dymond, 1977; Bischoff and Rosenbauer, 1977). Figure 2 shows ratios of several metals to aluminum, derived from the atomicabsorption data, in comparison with the same ratios for average Pacific pelagic clay. The upper part of the section studied in Hole 465A appears to be enriched in $\mathrm{Ni}$ and slightly enriched in $\mathrm{Cu}$ and $\mathrm{Co}$ relative to average Pacific pelagic clay. However, the diagnostic $\mathrm{Fe}$ and $\mathrm{Mn}$ enrichments are absent. 
Table 1. Summary statistics for total element concentrations in 24 samples of laminated limestone from Lithologic Unit II, Hole 465A.

\begin{tabular}{lccc}
\hline Element & $\begin{array}{c}\text { Observed } \\
\text { Range }\end{array}$ & $\begin{array}{c}\text { Arithmetic } \\
\text { Mean }\end{array}$ & $\begin{array}{c}\text { Standard } \\
\text { Deviation }\end{array}$ \\
\hline $\mathrm{Si}(\%)$ & $0.47-6.5$ & 2.6 & 1.7 \\
$\mathrm{Al}$ & $0.21-2.1$ & 0.83 & 0.59 \\
$\mathrm{Fe}$ & $0.046-1.6$ & 0.34 & 0.34 \\
$\mathrm{Mg}$ & $0.24-1.9$ & 0.50 & 0.40 \\
$\mathrm{Na}$ & $0.001-0.42$ & 0.15 & 0.14 \\
$\mathrm{~K}$ & $<0.017-0.78$ & 0.15 & 0.20 \\
$\mathrm{Ti}$ & $<0.013-0.16$ & 0.033 & 0.038 \\
$\mathrm{Ba}(\mathrm{ppm})$ & $8-230$ & 56 & 58 \\
$\mathrm{Co}$ & $<0.7-1.9$ & 1.0 & 0.38 \\
$\mathrm{Cr}$ & $3.6-62$ & 18 & 15 \\
$\mathrm{Cu}$ & $1.6-34$ & 9.2 & 9.1 \\
$\mathrm{La}$ & $<7.0-92$ & 25 & 25 \\
$\mathrm{Li}$ & $<7.0-20$ & 8.9 & 3.4 \\
$\mathrm{Mn}$ & $22-3700$ & 700 & 1100 \\
$\mathrm{Mo}$ & $<1.5-80$ & 24 & 19 \\
$\mathrm{Ni}$ & $4.5-120$ & 36 & 34 \\
$\mathrm{Sc}$ & $<0.70-6.7$ & 4.5 & 1.9 \\
$\mathrm{Sr}$ & $190-2300$ & 1300 & 600 \\
$\mathrm{~V}$ & $55-1000$ & 430 & 310 \\
$\mathrm{Y}$ & $1.0-55$ & 17 & 13 \\
$\mathrm{Yb}$ & $0.30-8.0$ & 3.0 & 2.0 \\
$\mathrm{Zr}$ & $11-370$ & 110 & 110 \\
\hline
\end{tabular}

Figures 3 and 4 compare the chemistry of rocks above basement in Hole 465A with the chemistry of sediments from both hydrothermal and normal pelagic areas. The laminated limestone and volcanic ash samples from Hole $465 \mathrm{~A}$ are more enriched in $\mathrm{Al}$ relative to $\mathrm{Fe}$ and Mn than metalliferous sediments from either the Bauer Deep or the East Pacific Rise, and more enriched in $\mathrm{Al}$

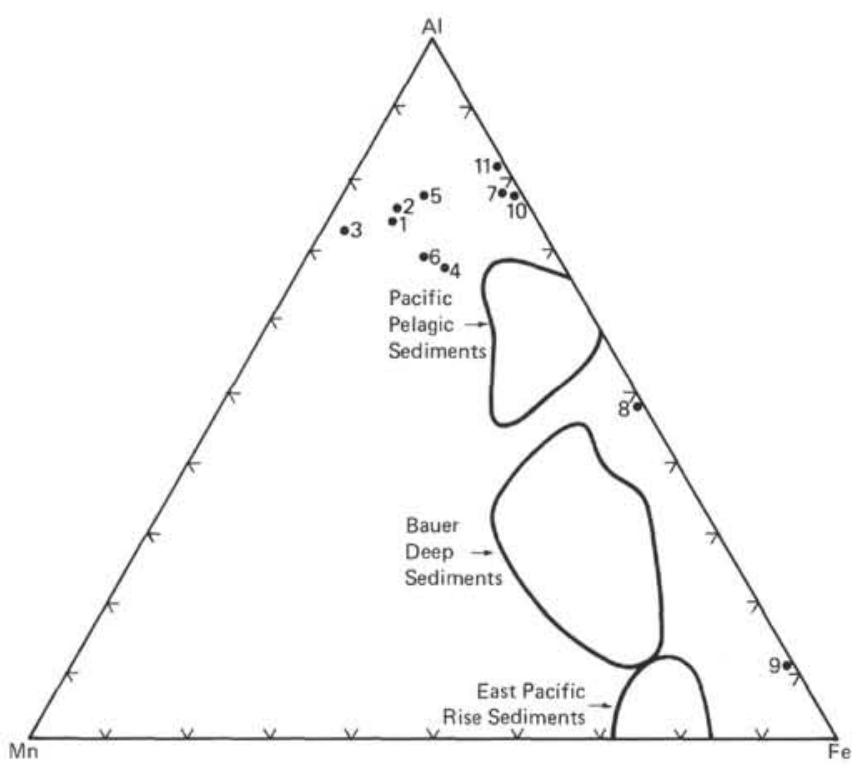

Figure 3. Triangular diagram showing relative concentrations of $\mathrm{Al}$, $\mathrm{Fe}$, and $\mathrm{Mn}$ in samples taken above trachyte basement at Site 465. Numbers correspond to sample numbers in Figure 1. Areas representing ranges of concentrations of $\mathrm{Al}, \mathrm{Fe}$, and $\mathrm{Mn}$ in sediments from the Bauer Deep, East Pacific Rise, and Pacific pelagic sediments are from Bischoff and Rosenbauer (1977).

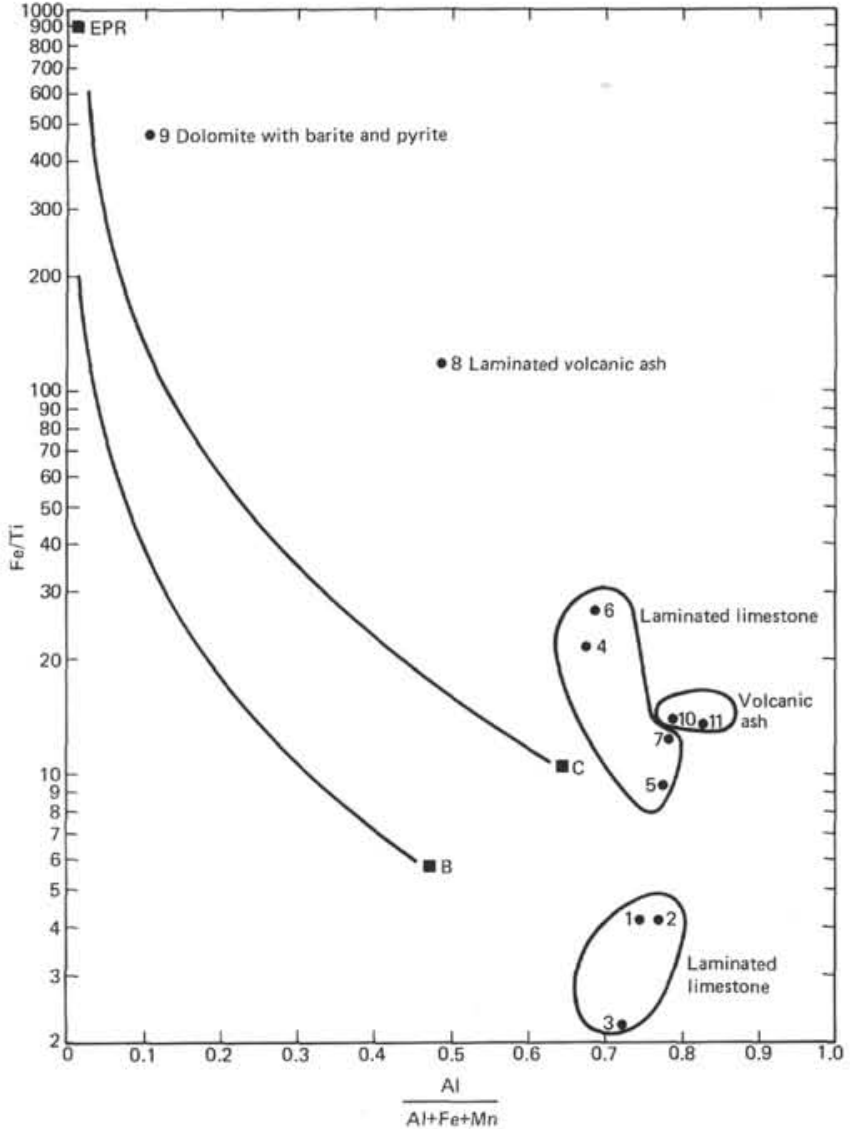

Figure 4. Plot of the ratios $\mathrm{Fe} / \mathrm{Ti}$ and $\mathrm{Al} /(\mathrm{Al}+\mathrm{Fe}+\mathrm{Mn})$ for samples taken above trachyte basement at Site 465 . Numbers correspond to sample numbers in Figure 1. Curves show mixing of average oceanic basalt (B) and average continental crust (C) with metalliferous sediment from the East Pacific Rise (EPR). Modified from Boström (1970).

than even Pacific pelagic sediments (Fig. 3). Samples 8 and 9 are enriched in $\mathrm{Fe}$ by the presence of pyrite, which causes them to appear to have a composition similar to Fe-rich metalliferous sediments enriched in oxides and hydroxides.

The curves in Figure 4 were constructed by Boström (1970) to illustrate mixing of metalliferous sediments from the East Pacific Rise (EPR) with either average oceanic basalt (B) or average continental crust (C). Boström and Peterson (1969) indicated that a value of less than 0.4 for the ratio $\mathrm{Al} /(\mathrm{Al}+\mathrm{Fe}+\mathrm{Mn})$ is indicative of metal enrichment in sediments. Figure 4 shows further that limestone and ash samples from Hole $465 \mathrm{~A}$ are $\mathrm{Al}$-rich and $\mathrm{Fe}$-poor in contrast to $\mathrm{Al}$-poor, Fe-rich sediments affected by hydrothermal solutions.

Figure 2 shows that the laminated limestone above trachyte basement at Site 465 is enriched in several elements, particularly Mo, Ni, V, and $\mathrm{Zn}$. However, lack of significant enrichment in $\mathrm{Fe}, \mathrm{Mn}, \mathrm{B}$, and $\mathrm{Ba}$, and the $\mathrm{Al}$-rich, Fe-poor, characteristics shown in Figures 3 and 4 , indicate that introduction of metals by hydrothermal solutions venting at the sea floor is unlikely. A com. parison with sediments altered by hydrothermal solutions percolating through the sediment column (Corliss 

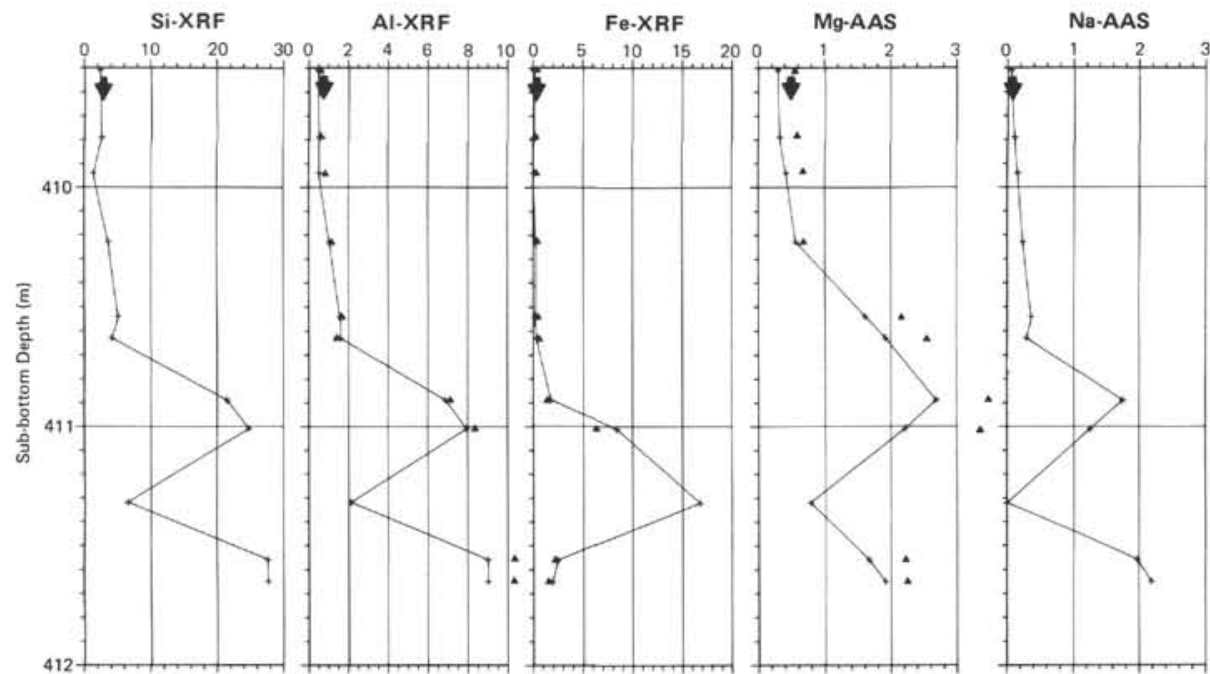

K.XRF
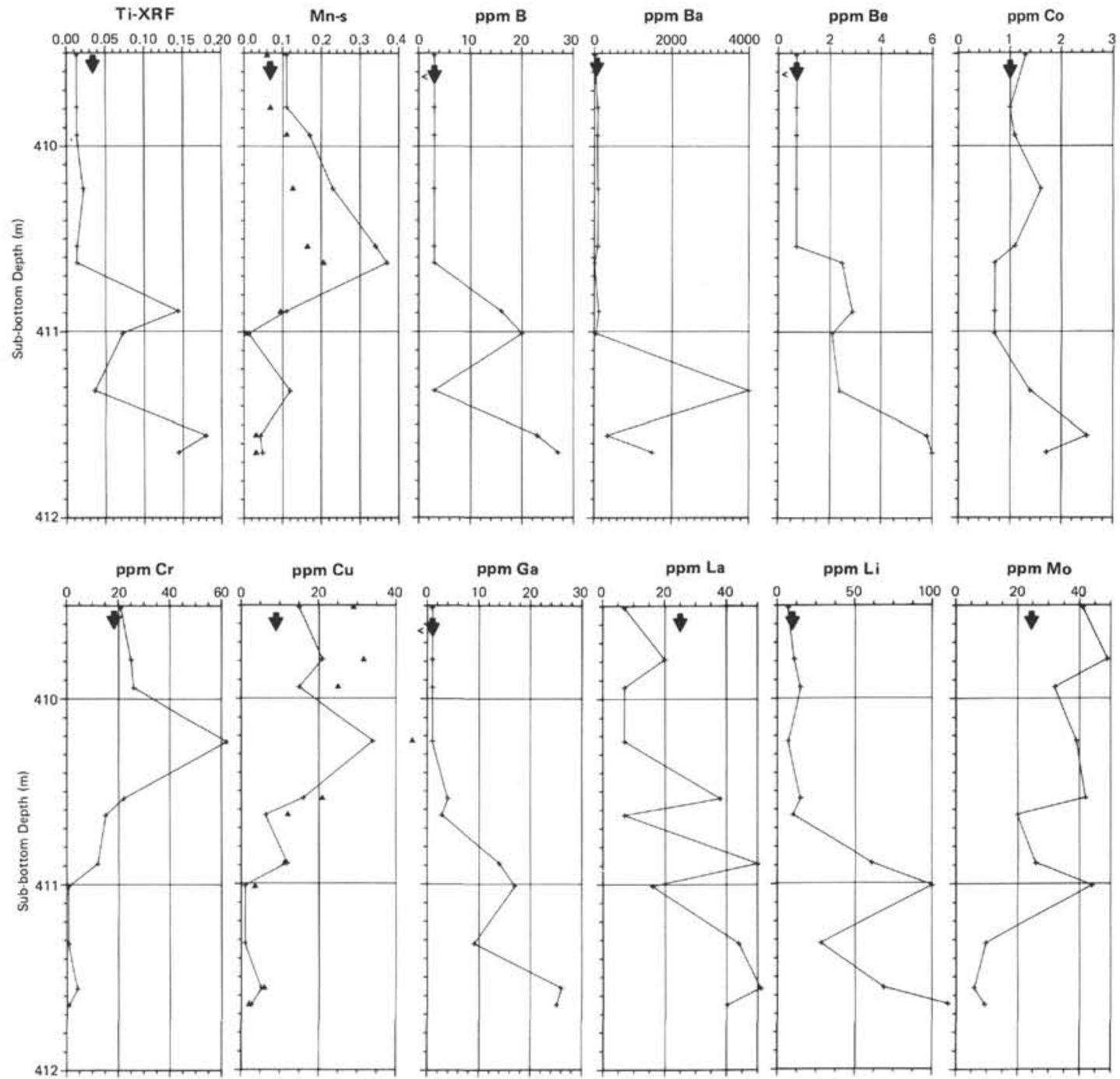

Figure 2. Plots of element concentrations and ratios of $\mathrm{Fe}, \mathrm{Mn}, \mathrm{Cu}, \mathrm{Co}$, and $\mathrm{Ni}$ to $\mathrm{Al}$ in samples from Core 40 , Hole $465 \mathrm{~A}$. Element concentrations are in percent or parts per million (ppm), dry weight. Analyses were by X-ray fluorescence (XRF), optical emission spectroscopy (s or no designation), or atomic-absorption spectroscopy (AAS). Results of analyses for $\mathrm{Al}, \mathrm{Fe}, \mathrm{Mg}, \mathrm{Mn}$, and $\mathrm{Cu}$ by atomic absorption spectrophotometry at Texas A\&M University are indicated by triangles. The arrow at the top of each concentration plot indicates the average concentration of each element in 24 samples of laminated limestone (Lithologic Unit II) listed in Table 1. The arrow at the top of each ratio plot is the ratio in average Pacific pelagic clay (APPC). 
GEOCHEMISTRY OF ROCKS ABOVE TRACHYTE BASEMENT
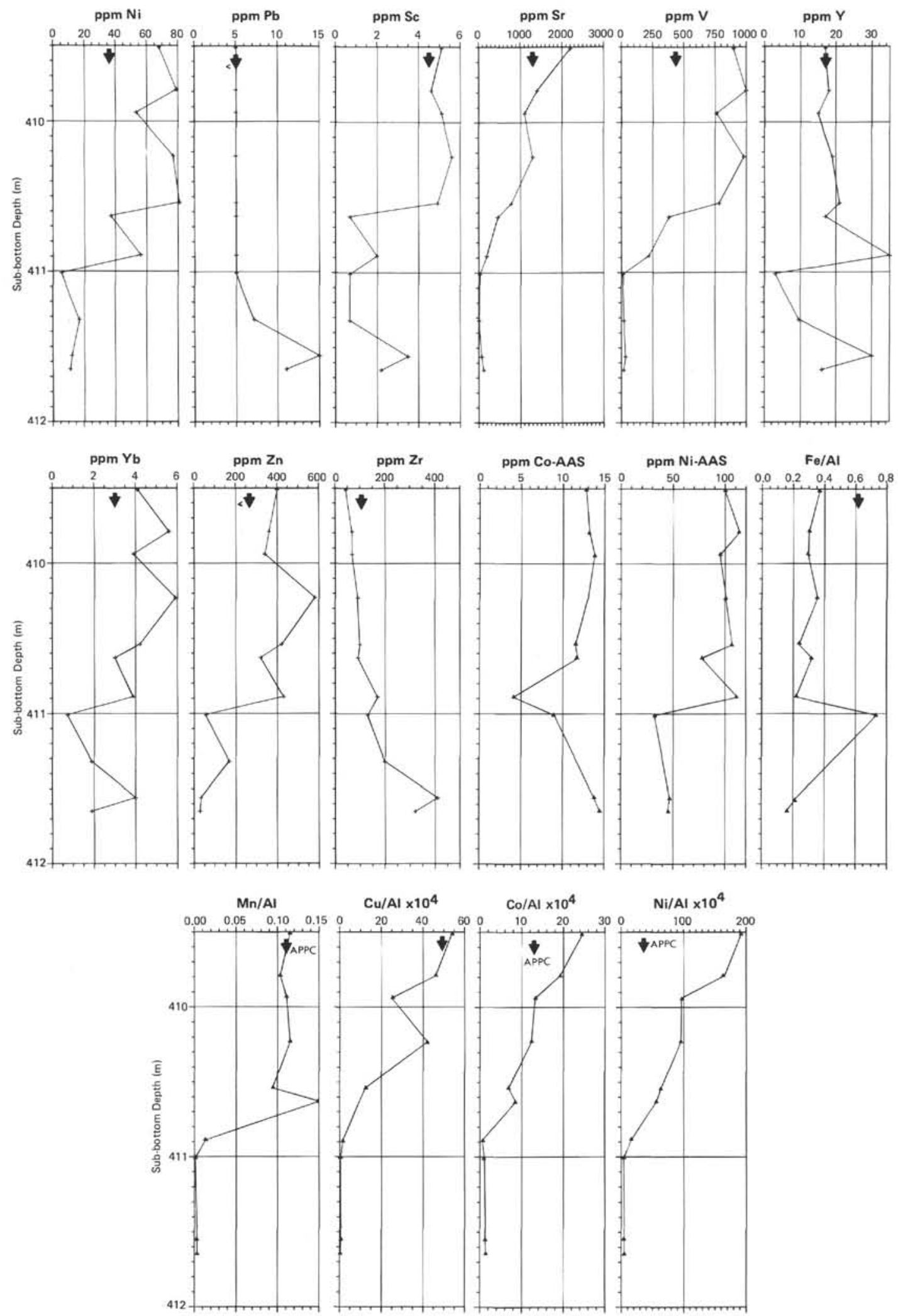

Figure 2. (Continued). 
et al., 1978; Scott et al., 1979; Natland, et al., 1979) also shows that the concentrations of metals in rocks above basement in Hole 465A are not high enough to suggest hydrothermal enrichment.

O'Neil and Vallier (this volume) have examined oxygen and sulfur isotopes in calcite, barite, and pyrite from the mineralized zone above trachyte basement in Core 40, Hole 465A. They concluded that the minerals formed in water at about $35^{\circ} \mathrm{C}$. Although $35^{\circ} \mathrm{C}$ is low compared to vent temperatures of $380^{\circ} \mathrm{C}$ determined on the East Pacific Rise (Spiess et al., 1980), it is higher than normal sea-floor $\left(2\right.$ to $\left.4{ }^{\circ} \mathrm{C}\right)$ or sea-surface temperatures. The formation of pyrite, barite, dolomite, and calcite indicates that there has been some redistribution of materials in the rocks above basement in Hole 465A, but the chemical data discussed in this paper suggest that no typical hydrothermal activity has taken place. However, the evidence for some remobilization of trace metals and a temperature of $35^{\circ} \mathrm{C}\left(\mathrm{O}^{\prime} \mathrm{Neil}\right.$ and Vallier, this volume) suggest the possibility of localized warming of pore fluids that subsequently resulted in the altered chemistry of the laminated limestone immediately above basement. The system apparently was not related to massive circulation of sea water through the crust that has been found in active spreading centers.

\section{ACKNOWLEDGMENTS}

We acknowledge useful reviews by J. R. Herring, B. J. Presley, and P. F. Salter, Computer graphics were prepared by G. H. Harrach.

\section{REFERENCES}

Bischoff, J. L., and Rosenbauer, R. J., 1977. Recent metalliferous sediment in the North Pacific manganese nodule area. Earth Planet. Sci. Lett., 33:379-388.

Bonatti, E., Kolla, V., Moore, W. S., and Stern, C., 1979. Metallogenesis in marginal basins: $\mathrm{Fe}$-rich basal deposits from the Philippine Sea. Mar. Geol., 32:21-37.

Boström, K., 1970. Submarine volcanism as a source for iron. Earth Planet. Sci. Lett., 9:348-354.

Boström, K., and Peterson, M. N. A., 1969. The origin of aluminumpoor ferromanganoan sediments in areas of high heat flow on the East Pacific Rise. Mar. Geol., 7:427-447.

Boström, K., Peterson, M. N. A., Joensuu, O., et al., 1969. Aluminum-poor ferromanganoan sediments on active oceanic ridges. $J$. Geophys. Res., 74:3261-3270.
Corliss, J. B., Lyle, M., Dymond, J., et al., 1978. The chemistry of hydrothermal mounds near the Galapagos Rift. Earth Planet. Sci. Lett., 40:12-24.

Dymond, J., Corliss, J. B., Heath, G. R., et al., 1973. Origin of metalliferous sediments from the Pacific Ocean. Geol. Soc. Am. Bull., 84:3355-3372.

Flanagan, F. J., 1973. 1972 values for international geochemical reference samples. Geochim. Cosmochim. Acta, 37:1189-1200.

Heath, G. R., and Dymond, J., 1977. Genesis and transformation of metalliferous sediments from the East Pacific Rise, Bauer Deep, and Central Basin, northwest Nazca plate. Geol. Soc. Am. Bull., 88:723-733.

Hekinian, R., Fevrier, M., Bischoff, J. L., et al., 1980. Sulfide deposits from the East Pacific Rise near $21^{\circ} \mathrm{N}$. Science, 207:14331444.

Manheim, F. T., Hathaway, J. L., Flanagan, F. J., et al., 1976. Marine mud, MAG-1, from the Gulf of Maine. In Flanagan, F. J. (Ed.), Descriptions and Analyses of Eight New USGS Rock Standards: U.S. Geol. Survey Prof. Paper, 840:25-28.

Miesch, A. T., 1976. Geochemical survey of Missouri-methods of sampling, laboratory analysis, and statistical reduction of data. U.S. Geol. Survey Prof. Paper, 954-A.

Natland, J. H., Rosendahl, B., Hekinian, R., et al., 1979. Galapagos hydrothermal mounds; stratigraphy and chemistry revealed by deep-sea drilling. Science, 204:613-615.

Rona, P., 1976. Pattern of hydrothermal mineral deposition: MidAtlantic Ridge crest at latitude $26^{\circ} \mathrm{N}$. Mar. Geol., 21:M59-M66.

Rona, P., Harbison, R. N., Bassinger, B., et al., 1976. Tectonic fabric and hydrothermal activity of Mid-Atlantic Ridge crest (lat. $26^{\circ} \mathrm{N}$ ). Geol. Soc. Am. Bull., 87:661-674.

Sayles, F. L., and Bischoff, J. L., 1973. Ferromanganoan sediments in the equatorial east Pacific. Earth Planet. Sci. Lett., 19:330-336.

Sayles, F. L., Ku, T. L., and Bowker, P. C., 1975. Chemistry of ferromanganoan sediment of the Bauer Deep. Geol. Soc. Am. Bull., 86:1423-1431.

Scott, M. R., and Bolger, G. W., in press. Metallogenesis in the Parece Vela Marginal Basin complex of the Philippine Sea. In Kroenke, L., Scott, R. B., et al., Init. Repts. DSDP, 59: Washington (U.S. Govt. Printing Office).

Scott, M. R., Salter, P. F., and Barnard, L. A., 1979. Chemistry of ridge-crest sediments from the North Atlantic Ocean. In Talwani, M., Harrison, C. G., and Hayes, C. E. (Eds.), Deep Drilling Results in the Atlantic Ocean Crust: Washington (Am. Geophys. Union), pp. 403-428.

Spiess, F. N., MacDonald, K. C., Atwater, T., et al., 1980. East Pacific Rise: hot springs and geophysical experiments. Science, 207:1421-1444.

Varentsov, I. M., 1978. The geochemistry of heavy metals in upper Cenozoic sediments near the crest of the Mid-Atlantic Ridge, latitude $23^{\circ} \mathrm{N}$, drilled on DSDP Leg 45. In Melson, W. G., Rabinowitz, W. G., et al., Init. Repts. DSDP, 45: Washington (U.S. Govt. Printing Office), 349-377. 